\title{
ON THE IMPORTANCE OF CIRCUMLOCUTION IN THE SPANISH LANGUAGE CLASSROOM
}

\author{
Deborah ARTEaga \& LuCÍA LLORENTE \\ University of Nevada, Las Vegas - Berry College \\ deborah.arteaga@unlv.edu - lllorente@berry.edu
}

\begin{abstract}
Resumen
Arteaga and Llorente (2009) abogan en favor de la importancia de tratar la variedad léxica regional en las clases de español como lengua extranjera. Proponen enseñar a los alumnos términos que sean neutros desde el punto de vista dialectal, que puedan entenderse en cualquier país hispanoparlante. Este enfoque, sin embargo, presenta el problema de que no siempre es fácil identificar cuáles son las palabras que tienen más difusión entre los dialectos. Este artículo aboga por suplementar el uso de los términos neutros con la destreza de la circunlocución, que diversos investigadores (Rubin, 1975; Oxford and Nyikos, 1989; Schweers, 1999) consideran de gran valor para los estudiantes de una segunda lengua en general, aunque deba ser enseñada explícitamente. Se ofrecen ejercicios modelo que fomentan el uso de la circunlocución, al mismo tiempo que hacen hincapié en los términos neutros. Esta combinación permitirá a los estudiantes comunicarse eficazmente con hablantes de una amplia gama de dialectos.
\end{abstract}

PALABRAS CLAVE: variedad lexica, ELE circunloción, dialectología, pluricentrismo.

\begin{abstract}
Arteaga and Llorente (2009) argue for the importance of addressing lexical regional variety in the Spanish language classroom. They advocate teaching students a dialectally neutral term that will be understood across dialectal zones. One problem with this approach, however, is the difficulty of identifying words that have the most currency among dialects. This paper argues for supplementing the use of neutral terms by the skill of circumlocution, which has been argued to be a valuable skill for second language learners in general (Rubin, 1975, Oxford and Nyikos, 1989, Schweers, 1999), although it must be taught explicitly. Model exercises that foster the use of circumlocution, while also emphasizing neutral terms, are given. This combination will allow students to communicate effectively with speakers of a wide variety of dialects.
\end{abstract}

KEY WORDS: lexical regional variety, Spanish as a second language, circumlocution, dialectology, pluricentrism.

\section{Introduction}

Spanish has roughly 400 million speakers, 328, 518, 810 L1 speakers and 60,000,000 L2 speakers, and is considered the second most spoken language in the world (Lewis, 
2009). It is the official language of 20 countries, and is spoken by groups of various sizes in other 20 countries. In the U.S., according to the 2010 Census population count, there are 50.5 million Hispanics, which amounts to $16 \%$ of the total population. This is an increase of $43 \%$ with respect to the 2000 Census. Every state shows a growth in its Hispanic population, with states in the South showing the biggest changes.

The impact of Spanish has also been felt in the classroom. Ever since 1970, Spanish has been the foreign language with the biggest enrollments in postsecondary institutions in the US. In a recent MLA survey, there were roughly 900,000 Spanish students, about 55.500 more students than students of all the other languages combined. Table (1), based on Fall 2009 Enrollments in U.S. Institutions of Higher Education, illustrates these data (Furman et alii, 2010:19):

(1)

\begin{tabular}{|c|c|c|c|c|c|}
\hline \multicolumn{6}{|c|}{$\begin{array}{c}\text { Table 1a Fall 2002, 2006, and } 2009 \text { Language Course Enrollments (Languages in Descending } \\
\text { Order of } 2009 \text { Totals) }{ }^{1}\end{array}$} \\
\hline & \multirow[t]{2}{*}{2002} & \multirow[t]{2}{*}{2006} & Change & \multirow[t]{2}{*}{2009} & Change \\
\hline & & & $2002-06$ & & 2006-2009 \\
\hline Spanish & 746,267 & 822,985 & 10.3 & 864,986 & 5.1 \\
\hline French & 201,979 & 206,426 & 2.2 & 216,419 & 4.8 \\
\hline German & 91,100 & 94,264 & 3.5 & 96,349 & 2.2 \\
\hline ASL & 60,781 & 78,829 & 29.7 & 91,763 & 16.4 \\
\hline Italian & 63,899 & 78,368 & 22.6 & 80,752 & 3.0 \\
\hline Japanese & 52,238 & 66,605 & 27.5 & 73,434 & 10.3 \\
\hline Chinese & 34,153 & 51,582 & 51.0 & 60,976 & 18.2 \\
\hline Arabic & 10,584 & 23,974 & 126.5 & 35,083 & 46.3 \\
\hline Latin & 29,841 & 32,191 & 7.9 & 32,606 & 1.3 \\
\hline Russian & 23,921 & 24,845 & 3.9 & 26,883 & 8.2 \\
\hline Greek, Ancient & 20,376 & 22,849 & 12.1 & 20,695 & -9.4 \\
\hline Hebrew, Biblical & 14,183 & 14,140 & -0.3 & 13,807 & -2.4 \\
\hline Portuguese & 8,385 & 10,267 & 22.4 & 11,371 & 10.8 \\
\hline Korean & 5,211 & 7,145 & 37.1 & 8,511 & 19.1 \\
\hline Hebrew, Modern & 8,619 & 9,612 & 11.5 & 8,245 & -14.2 \\
\hline Other languages & 25,716 & 33,728 & 31.2 & 40,747 & 20.8 \\
\hline Total & $1,397,253$ & $1,577,810$ & 12.9 & $1,682,627$ & 6.6 \\
\hline
\end{tabular}

\footnotetext{
${ }^{1}$ The apparent drop in Ancient Greek may be attributed to changes in reporting; in earlier surveys, languages such as Biblical Greek, Koine Greek, and other premodern Greek language categories may have been reported under the category "Ancient Greek”.
} 
This extraordinary number of students is a direct result of the overwhelming presence of Spanish speakers in this country. Many of those 50.5 million Hispanics living in the US reported by the Census of 2010 are monolingual Spanish speakers. The knowledge of Spanish is, therefore, an important asset when entering the work force, and many students study Spanish for that reason.

Another feature of the Spanish-speaking population in the U.S., is that speakers come from different countries. The most recent data for the 2010 Census is not available yet, but we can see this diversity in table (2) below, which gives a breakdown of the country of origin of the U.S. Hispanic population as of 2009:

(2) Pew Hispanic Center, Statistical Portrait of Hispanics in the United States, Detailed Hispanic Origin

$\begin{array}{lll}\text { Mexican } & 31,673,700 & 65.5 \\ \text { Puerto Rican } & 4,411,604 & 9.1 \\ \text { Salvadoran } & 1,736,221 & 3.6 \\ \text { Cuban } & 1,677,158 & 3.5 \\ \text { All Other Spanish/Hispanic/Latino } & 1,640,180 & 3.4 \\ \text { Dominican } & 1,360,476 & 2.8 \\ \text { Guatemalan } & 1,077,412 & 2.2 \\ \text { Colombian } & 916,616 & 1.9 \\ \text { Honduran } & 624,533 & 1.3 \\ \text { Spaniard } & 613,585 & 1.3 \\ \text { Ecuadorian } & 611,457 & 1.3 \\ \text { Peruvian } & 557,107 & 1.2 \\ \text { Nicaraguan } & 368,720 & 0.8 \\ \text { Argentinean } & 227,180 & 0.5 \\ \text { Venezuelan } & 198,276 & 0.4 \\ \text { Panamanian } & 170,057 & 0.4 \\ \text { Costa Rican } & 131,331 & 0.3 \\ \text { Chilean } & 122,986 & 0.3 \\ \text { Bolivian } & 104,044 & 0.2 \\ \text { Uruguayan } & 56,054 & 0.1 \\ \text { Other Central American } & 31,912 & 0.1 \\ \text { Other South American } & 19,356 & 0.0 \\ \text { Paraguayan } & 18,179 & 0.0 \\ \text { Total } & 48,348,144 & 100.0 \\ & & \end{array}$

As can be seen from the above table, while $65.5 \%$ of Hispanics have Mexico as their country of origin, the remaining $35.5 \%$ do not. 
The fact that Spanish speakers in the U.S. come from several different geographical regions is relevant for our students. Indeed, a very important feature of Spanish, in comparison to many other languages, is its pluricentricity, that is, the fact that it has several, not just one, prestige norm. In Spanish there is no single standard variety, quite the contrary; we could say that every dialect has its own standard variety.

Spanish students, then, are going to be in contact with a great range of native speakers, originating from very different regions of the Spanish-speaking world. This will be the case both outside and inside of the classroom, where instructors might represent different dialects of the language. Moreover, among the Spanish students themselves, we will find many heritage speakers, who grow up speaking Spanish at home. These heritage speakers will also bring a certain geographical variety of Spanish to the classroom.

In Spanish, dialectal differences are manifested in all linguistic areas, but are particularly relevant in the lexicon. Although the high level of intradialectal variability adds to the richness and flavor of the language, it also poses several unique challenges for instructors. Some simply leave dialectal variation out of their instruction, aiming instead to teach a non-existent, or textbook variety, of the language, that at times combines features of several dialects.

Arteaga and Llorente (2009) have addressed these topics in detail and advocate the necessity to make students aware of the pluricentricity of the Spanish language. We next present an overview of their proposal.

\section{Review of Arteaga and Llorente (2009)}

Arteaga and Llorente (2009) argue that lexical variation among dialects must be addressed in the Spanish language classroom. Their proposal is threefold: 1) to raise the metalinguistic awareness of students, in the sense of Cook (2008), specifically to make them aware of the fact that dialectal differences exist in Spanish and that these are reflected in the lexicon 2) for students to actively learn neutral terms, by which they mean words that are generally understood across dialects. 3) for students to come to passively understand alternate terms in the most common Spanish dialects in their region.

They acknowledge that this may be a challenge, particularly because of the fact that first-year Spanish textbooks at the university level do not emphasize either dialectal variation with respect to the lexicon nor the active/passive dichotomy of lexical acquisition. As they note, textbooks take one (or both) of the following approaches: 1) a "smorgasbord approach," by which they mean that the students are given a list of lexical 
dialectal variants without an explanation of which has the most currency among dialects 2) "a cafeteria approach", meaning that textbooks randomly pick and choose words from a variety of dialects.

As an example of the smorgasbord approach, they note that in the popular university-level textbook Plazas (Hershberger et alii, 2008). Both café and marrón are used for the word 'brown,' with no indication as to where these terms are found. Their examples of the cafeteria approach include a chapter introducing clothing, in the same textbook. It presents vaqueros for 'blue jeans,' a term from Peninsular Spanish (in Latin America, common terms include blujeanes and pantalón de mezclilla), yet for the word 'earring' they give aretes, clearly from Latin America, as the Spanish term would be pendientes.

In our opinion, the approach suggested by Arteaga and Llorente (2009) has a great deal of merit. It is a serious attempt to expose students to the notion of lexical dialectal differences and to navigate these differences in cases where there is a great deal of lexical variation. It emphasizes that these two skills are essential if bilateral communication is to take place. If students want to be understood, they should use a word that is likely to be understood by speakers hailing from a wide variety of countries. Conversely, for them to understand the Spanish that is directed at them, they should have a good general understanding of how common words vary across dialects.

However, Arteaga and Llorente's proposal is not without its problems. The most serious is the fact that it is not always possible for the instructor to readily identify which terms are neutral, and which are not. Consider the following table (cited in Arteaga and Llorente; adapted from Azevedo (1992: 344):

(3) Lexical variation: Most common terms in five countries ${ }^{2}$

$\begin{array}{lllll}\text { España } & \text { Argentina } & \text { Puerto Rico } & \text { México } & \text { El Salvador } \\ \text { acera } & \text { vereda } & \text { acera } & \text { banqueta } & \text { acera } \\ \text { autocar } & \text { colectivo } & \text { guagua } & \text { camión } & \text { camioneta } \\ \text { americana } & \text { saco } & \text { gabán } & \text { saco } & \text { saco } \\ \text { bañador } & \text { malla } & \text { traje de baño } & \text { traje de baño } & \text { calzoneta } \\ \text { cajón } & \text { cajón } & \text { gaveta } & \text { cajón } & \text { cajón } \\ \text { calcetines } & \text { zoquetes } & \text { medias } & \text { calcetines } & \text { calcetines } \\ \text { cazadora } & \text { campera } & \text { jacket } & \text { chamarra } & \text { chumpa } \\ \text { gabardina } & \text { piloto } & \text { capa } & \text { impermeable } & \text { capa }\end{array}$

\footnotetext{
${ }^{2}$ Glosses: sidewalk, bus, sports coat, swimsuit, drawer, socks, coat, raincoat, glasses, block, swimming pool, apartment.
} 


\begin{tabular}{|c|c|c|c|c|}
\hline gafas & $\begin{array}{l}\text { lentes, } \\
\text { anteojos }\end{array}$ & espejuelos & $\begin{array}{l}\text { lentes, } \\
\text { anteojos }\end{array}$ & anteojos \\
\hline manzana & cuadra & manzana & cuadra & manzana \\
\hline piscina & pileta & piscina & alberca & piscina \\
\hline piso & departamento & apartamento & departamento & apartamento \\
\hline
\end{tabular}

The above table illustrates the great lexical differences among Spanish dialects. In some cases, such as the word for 'drawer,' it appears to be easy to choose the neutral term, which would be cajón. The same can be said for the word for 'apartment,' which, at first glance, varies widely among the dialects, Peninsular Spanish has piso, while the other dialects are evenly split between apartamento and departamento. However, the term apartamento is clearly the neutral term as it would be understood across dialects, although in Spain it refers to a studio appartment.

However, in cases like 'jacket,' the dialects have such strikingly different words that the selection of a neutral one seems not only difficult, but arbitrary, as can be seen in Table 3 above. The terms are cazadora (Spain), campera (Argentina), jacket (Puerto Rico), chamarra (Mexico), and chumpa (El Salvador). Which term is the neutral term in such a case?

A similar problem with Arteaga and Llorente's approach is that the fact that a term is found more commonly does not mean that it has the most currency. Consider 'raincoat': two dialects (Puerto Rico and El Salvador) appear to share a word, capa, but this word has a very different meaning ('cape') in the dialects where it is not used. Finally, consider a vocabulary item such as 'block,' where the terms seem to be evenly spread, as Spain, Puerto Rico and El Salvador use manzana, while Argentina and Mexico use cuadra. Moreover, in Spain, cuadra means a stable for animals.

One possibility, of course, is to select the term used in Mexico, since as we have seen, above in Table 2, (origin of Hispanics) roughly $66 \%$ of the Hispanic immigrants in the U.S. are of Mexican origin. However, there is still a large percentage of speakers who do not speak this geographical variety. They may have difficulty understanding a term that is completely different from the one used in their dialect. This is particularly seen in speakers who lack formal education, or have never traveled, as they may not have been systematically exposed to dialects other than their own.

Another problem with this approach is that even in the cases where a neutral term can be readily identified, Spanish instructors and Graduate Teaching Assistants may be unable to do so, as they generally lack linguistic preparation. As noted by Arteaga and Llorente, instructors typically have a prescriptive view of dialects, in which they view one vocabulary item (generally their own!) as the standard term, and all others as sub- 
standard. Alternatively, they simply teach the vocabulary in the textbook without pointing out dialectal variation or neutral terms. The fact that textbooks do not use the approach advocated in Arteaga and Llorente greatly complicates the matter for these instructors.

In our view, then, if the goal for our students is to communicate with speakers of different dialects, the use of a neutral term must be supplemented by another aspect of strategic competence (Canale and Swain, 1980). We next turn to a theoretical overview of the importance of the lexicon.

\section{Theoretical Background}

It has been noted by several researchers, including Gass and Selinker (2001) and Parikbaht $(1985 ; 1986)$, that lexical competence is paramount to bilateral communication. For instance, consider the following example from Spanish:

(4) NNS Tengo que atender mi clase. 'I have to attend my class.'

NS ¿Qué cosa? No entiendo. 'What? I don't understand'

Such a strategy is referred to as an L2 strategy, because the word used is a Spanish word, with Spanish pronunciation. The problem with the above exchange is that while the word atender does exist in Spanish, it means' to attend to' (i.e., a person). If the speaker wishes to express the term for attend an event in Spanish s/he must use asistir $a$. As another example of an L2 strategy, consider the following:

(5) NNS Mi comandante es comunicaciones, 'My major (literally commander) is communications.' (cf. 'Mi especialidad...'

NS No entiendo lo que dices. 'I don't understand what you are saying.'

In the above error, the student has confused 'major' (academic specialty) with 'major' (commander). The NS has no idea what the NNS means.

Another possibility is for the NNS to create a word that does not exist in the target language, known as word coinage, another L1 strategy, as in the following:

(6) NNS Si ganara la lotería, aviaría a Francia.

NS ¿Qué dices?

The non-native speaker has taken the term for airplane (avión) and turned it into a verb ( ${ }^{*}$ aviar). The correct form would be viajaría 'I would travel to' or iría 'I would go to.' 
Another example of an L1 strategy is simply inserting a word from a learner's native language, with foreignization, (i.e., adapting the word to the L2 phonology) or without (code switching). An example of the former can be seen by the following exchange:

(7) NNS Quiero comprar un queque. 'I want to buy a cake' NS ¿Qué quieres comprar?'What do you want to buy?

In the above dialogue, the NNS has taken the English word 'cake' and adapted it to Spanish phonotactics [kéke]. If the NNS were to simply insert the word 'cake,' pronouncing it as [kéjk], this would be an example of code-switching, which is only successful when speaking to bilinguals ${ }^{3}$.

What is relevant to the present paper are instances in which dialectal differences are the root of lexical misunderstandings. For example, the NNS may use a dialectal variant for a term that means something different for the NS:

(8) NNS Necesitas un piloto. Llueve mucho. 'You need a raincoat. It rains a lot.' NS ¿Un piloto? ¿Por qué? No tengo avión. 'A pilot? Why? I don't have an airplane.'

NNS Does not know what to say

The NNS has used a word for 'raincoat' piloto (found in Argentinian Spanish) that means only 'pilot' in the NS' dialect. Note that the dialogue could have been reversed, in that the NS could have used the word piloto for raincoat. However, in that case, the NS would have likely used a repair strategy (see Section 3 below).

Similarly, the NNS may use a dialectal variant that has no meaning in the NS' lexicon.

(9) NNS Todos mis zoquetes están sucios. 'All of my socks are dirty.'

NS ¿Zoquetes? ¿Qué cosa es? 'Zoquetes? What is that?'

NNS Does not know what to say.

In these last two examples, the student was unable to choose a neutral term to express a lexical item (cf. Arteaga and Llorente). Again, what is missing here is a communication strategy to account for the lack of comprehension on the part of the NS.

\footnotetext{
${ }^{3}$ Willems (1987) refers to L1 strategies as "intralingual" as opposed to L2 strategies, which he calls "interlingual." Bialystok and Fröhlich (1980), in a study of 43 French L2 speakers, shows that this strategy is by far the least effective. Bialystock (1983:106) also argues that L1 strategies used by the L2 speaker fail, because the addressee does not speak L2 speaker's native language.
} 
But note that regardless of the source of the lexical error, in all of the above exchanges, there is a breakdown of communication. On the other hand, if the L2 speaker makes instead a grammar mistake, s/he would most likely be understood (cf. Gass and Selinker, 1986; Van Patten, 2004).

(10) NNS *Ayer iba al cine. 'Yesterday I was going/used to go to the movies.' (Target utterance: Ayer fui al cine. 'Yesterday I went to the movies.') NS ¿Qué película viste? 'What movie did you see?

The NNS has used a verbal aspect (imperfect) that denotes an action in progress or a habitual action in the past ( $i b a$, 'I was going/I used to go' vs. the correct fui 'I went'). However, this does not keep the NS from understanding the NNS. Note that in his/her answer, s/he uses the preterit aspect (viste 'did you see' instead of veías 'were you going to see/did you used to see'). Importantly, the conversation continues despite the NNS' error.

In the next section, we present the theoretical framework regarding circumlocution. in which we ground our proposal for teaching the lexicon.

\section{Circumlocution: Theoretical background}

Many previous works have stressed the importance of "communication strategies" or the linguistic tools at the disposal of an L2 to successfully interact with an L1 speaker for the development of "communicative competence" (see inter alia Tarone, 1977; Canale and Swain, 1980; Savignon, 1983; Paribakht, 1985; Dörneyi and Thurrell, 1991, and Jourdain, 2000). It is one skill that students can use when linguistic repair is needed. With respect to the lexicon, under this rubric, these authors include circumlocution (oftentimes referred to as paraphrase, e.g., the thing you drink coffee from (for cup), as well as the use of analogy (e.g., foots for feet), a superordinate term (furniture for table), synonyms (car for auto), word coinage (warish for warlike), and avoidance (don't use the term). In this paper, we consider all but the last option to be encompassed by the term circumlocution. We define circumlocution broadly, namely as the ability to explain a lexical concept for which the L2 speaker has no word (or can retrieve none) in his/her lexicon (cf. Jourdain, 1985; 2000).

\footnotetext{
${ }^{4}$ Note that for these authors, such as Canale and Swain (1980), communicative competence also includes the following types of competence: grammatical, sociolinguistic, and strategic competence.
} 
Several scholars (inter alia Berry-Bravo, 1994; Liskin-Gasparo, 1996; Salomone and Marsal, 1996; Jourdain, 2000) have pointed out that circumlocution is spelled out in the ACTFL guidelines. In the latest version of the proficiency guideline on speaking, circumlocution, as an effective communicative strategy, is one of the defining characteristics of Advanced High, and Intermediate-High, speaking levels: ${ }^{5}$

(11) Advanced High

Advanced-High speakers may demonstrate a well-developed ability to compensate for an imperfect grasp of some forms or for limitations in vocabulary by the confident use of communicative strategies, such as paraphrasing, circumlocution, and illustration. (emphasis ours).

Advanced Mid

Advanced-Mid speakers can handle successfully and with relative ease the linguistic challenges presented by a complication or unexpected turn of events that occurs within the context of a routine situation or communicative task with which they are otherwise familiar. Communicative strategies such as circumlocution or rephrasing are often employed for this purpose. (emphasis ours)

Advanced-low

Advanced-Low speakers demonstrate the ability to narrate and describe in all major time frames (past, present, and future) in paragraph length discourse, but control of aspect may be lacking at times. They can handle appropriately the linguistic challenges presented by a complication or unexpected turn of events that occurs within the context of a routine situation or communicative task with which they are otherwise familiar, though at times their discourse may be minimal for the level and strained. Communicative strategies such as rephrasing and circumlocution may be employed in such instances.

For the intermediate mid level, a lack of effective circumlocution ability is noted:

(12) Intermediate mid

Intermediate-Mid speakers tend to function reactively, for example, by responding to direct questions or requests of information. However, they are capable of asking a variety of questions when necessary to obtain simple information to satisfy basic needs, such as directions, prices and services. When called on to perform functions or handle topics at the Advanced level, they provide some information but have difficulty linking ideas, manipulating time and aspect, and using communicative strategies, such as circumlocution. (124, emphasis ours).

\footnotetext{
${ }^{5}$ Circumlocution is not mentioned in the highest level, Superior. The guidelines can be found at http://www.actfl.org/i4a/pages/index.cfm?pageid=4236.
} 
Finally, for levels below Intermediate Mid (e.g., Intermediate Low, Novice High, Novice Mid, and Novice Low levels), circumlocution is not mentioned, as students at these levels do not effectively use sophisticated communicative strategies'.

\subsection{Circumlocution as negotiation}

In the broadest sense, circumlocution can be viewed as a type of negotiation (Long, 1993). After all, communication has broken down and one or both parties are attempting to remedy this. According to Long, speakers have at their disposal various means with which to negotiate meaning: the use of comprehension checks, in which the speaker wants to make sure that the listener has understood; confirmation checks, in which the listener confirms to the speaker that $\mathrm{s} /$ he has understood the message; and clarification requests, where the interlocutor, who has not understood the speaker, makes that known.

Many scholars have advocated negotiation for successful communication between the NS and the NNS. One aspect is the ability to comprehend the NS (Pica, 1991, Gass and Varonis, 1994; Loschy, 1994) ${ }^{7}$. A second aspect is the ability to produce the output that will aid in communication (e.g., Pica, 1992; Pica et alii, 1991).

Relevant to our discussion is also the Output Hypothesis proposed by Swain (1985), in which production of the L2 is viewed as equally important as "comprehensible input." (Krashen, 1991). As pointed out by Willems (1987), communication strategies can be both receptive and productive. We argue that both are necessary in the Spanish language classroom, because of the vast lexical differences among dialects. The student needs to be able to understand circumlocution, if a native speaker is trying to explain an unknown term, as well as produce it, if they need to communicate with a native speaker.

Not all scholars agree, however, with the effectiveness of negotiation for vocabulary acquisition. For example, Ehrlich et alii (1989) found that negotiation via explanation by the NS was actually detrimental to L2 students' comprehension of vocabulary. Pica $e t$ alii (1987) showed that while negotiation does facilitate comprehension, it does not lead to improved acquisition of the vocabulary (cf. Loschky, 1989). The results of Pica's

\footnotetext{
${ }^{6}$ Liskin-Gasparro (1996) argues that the use of circumlocution is actually a function of the Oral Proficiency Interview format. In her view, this is due to the fact that the interviewer does not 'rescue' the L2 speaker who is struggling with vocabulary as a NS would naturally do.

${ }^{7}$ See De la Fuente (2002) for a detailed discussion of works that advocate negotiation.
} 
(1992) study showed that negotiation is only valuable for low level students (cf. Long 1993).

Other studies, however, have shown that negotiation can be very helpful. Paribakht (1986) notes that as students' proficiency increases, the problems that they have with the lexicon can be better remedied (cf. Tarone, 1977; Biaystok and Fröhlich, 1980). In a study of 20 intermediate and advanced ESL students, and a control group of 20 native speakers, the advanced students, like the native speakers, had more communication strategies at their disposal. For example, to define pomegranate, these speakers would come up with circumlocutions such as the following: "it's small, it would fit in your hand".

Ellis et alii (1994), in two studies with respectively 79 and 127 L2 English L1 Japanese high-school students, found that while where students actively negotiated meaning, they understood new words better than those who did not. They interpreted this result to support Gass (1988), who makes the distinction between comprehensible input and comprehended input. For Gass, through negotiation, students can control the input until they have understood. Ellis et alii (1994) also found that negotiation aids acquisition.

Salomone and Marsal (1996) conducted a study of two classes of L2 French L2 English L1 university students. Students in both classes were administered a pretest, which consisted of the following in English: eleven concrete nouns, five abstract nouns, and four shapes. The students had to explain all of these using circumlocution. In addition, one of the groups was given a handout which explained to them how to circumlocute, and these students were asked to do so with new French vocabulary words. While there was no statistical difference between the groups, the post-test scores showed that the experimental group was able to better use circumlocution.

Another study that documents whether or not negotiation is necessary for vocabulary acquisition at earlier stages, is that of De la Fuente (2002). In a study of thirty-two intermediate L1 English L2 Spanish students, she showed that circumlocution (which she considers to be interaction), within a negotiated exchange by a NS or NNS, can be highly effective when a word is not known. Using ten Spanish words not known by

\footnotetext{
${ }^{8}$ However, as the authors note, students who actively study vocabulary on their own can also acquire it, despite the lack of negotiation (cf. Nation, 1990).

${ }^{9}$ The authors based this on studies such as Paribakht (1985) and Kellerman et alii (1990).
} 
these students, she found that indeed, negotiated input facilitated production of vocabulary, although not comprehension ${ }^{10}$.

She claims that the difference in production can be understood by viewing L2 vocabulary acquisition as what she refers to as "decoding" (comprehension) and "code breaking." The latter requires a deeper level of processing, in her view, because students had to focus on the form in order to achieve production of $\mathrm{it}^{11}$.

Salazar (2006), in a study of six intermediate students, Spanish L1 English L2, studied the importance of teaching circumlocution in the language classroom. The students were given several tasks. In the first one, they had to identify and place objects in an office, according to the directions of the researcher. Exchanges like the following were typical (Salazar, 2006: 10):

(13) Example 1

Researcher: Put the ashtray on the shelf

Student 1: What is the ashtray?

R: Ashtray? Imagine, if you smoke, you need an ashtray to leave your cigarette when

you finish it. Do you understand?

S1: Yes

S6: Where I can put the ashtray?

R: The ashtray... on the shelf. Right? The second. Put the rug on the floor.

In a second task, students were asked to put objects in different places, but no negotiation was possible. The purpose of this task was to see if the students actually retained the new vocabulary words. The third task was almost identical to the first one, except the items in question were in a bedroom and the students were working in pairs. Simi-

\footnotetext{
${ }^{10}$ This is not to say that we advocate the approach used in De la Fuente. For one, the words selected by De la Fuente include very low frequency words like la pacova, el terere, and la oga and are not in most dictionaries, including the Collins Dictionary español-inglés, English-Spanish (Butterfield, 2005). Her reason for including these terms, which she claims are found in unspecified Latin American dialects, was to ensure that students would have no prior contact, in her words, "avoiding the necessity of a pretest." Yet some of the words are widely used, such as elote 'corn.' For this reason, a pretest would have been advisable. We disagree with the author regarding actively teaching words that many native speakers will not understand. Moreover, the definitions provided to students, in our view, are quite sketchy (e.g., elote 'corn' El elote es una comida y tiene muchas partes pequeñas. No es una fruta. 'Elote is food, and it has many small parts. It is not a fruit').

${ }^{11}$ Van Patten (1994) has long argued this for the acquisition of morphology.
} 
lar negotiations to (13) above were seen in the exchanges between the students (Salazar, 2006: 11):

(14) Example 2

Student 2: Put the mug.. .

Student 3: What is mug?

S2: It's a... it's a kind of cup... cup... when you have coffee

S3: Ah

S2: You put it in a cup. This is a kind of cup which it's more

S3: OK

S2: More big. Put this mug on the small table.

She concludes that these intermediate students effectively used negotiation, specifically circumlocution in the exercises. In her view, these results point to the necessity of teaching circumlocution in the L2 language classroom.

\subsection{Should circumlocution be taught?}

If we assume that negotiation, specifically circumlocution, is important for our L2 speakers to have at their disposal, the question becomes if the skill can or should be taught explicitly. Many studies point to the necessity of overtly teaching circumlocution.

Rubin (1975: 42) discusses "Good Language Learners", by which she means those who have "aptitude, motivation and opportunity." She argues that among the characteristics of successful L2 speakers is the willingness to use circumlocution when s/he doesn't know a word. For Rubin, this springs from a desire to communicate with L1 speakers, part of a language use strategy ${ }^{12}$. She argues that teachers need to encourage opportunities for students to communicate in this way.

Similarly, Oxford and Nyikos (1989) note that one difference between good language learners and poor ones, is the ability of the former to use what they term "compensation strategies." These include the ability to circumlocute when necessary in order to understand and also produce the $\mathrm{L} 2$.

\footnotetext{
${ }^{12}$ Others include the ability to be a good guesser, the lack of inhibition shown by the effective L2 speaker, his/her attention to form, the fact that s/he uses the L2 wherever possible, his/her ability to focus on his/her output and that of others, his/her attempt to use the language whenever possible, and his/her drive to understand meaning.
} 
In a longitudinal study of a universiTy-level conversation course, Brooks (1992) notes that where students lack vocabulary, say in a pair or group activity, they code-switch into English. Such a strategy would render their speech incomprehensible to monolingual speakers of Spanish. He advocates teaching them the strategy of circumlocution as a solution ${ }^{13}$.

One important note is that textbooks rarely, if ever teach circumlocution as a strategy, particularly those at the beginning levels (cf. O’Malley, 1987; Dörnyei and Thurrell, 1991). Therefore it becomes all the more important that the instructor teach this skill to students.

\section{Teaching circumlocution}

\subsection{Previous proposals}

In the literature, there are many scholars who have given specific tips to teaching circumlocution. Willems (1987: 35) advocates explanation of paraphrase and then giving students pictures of unknown words that they have to explain to each other. For example, for a colander, they would need to use phrases like: "it's made of metal . . it has a silver color ... it is bowl-shaped." As another exercise, he advocates the use of crossword puzzles. In this exercise, each student has half of the cross-word puzzle filled in and must explain to his/her partner what the word is instead of just giving word.

As another example, Tarone and Yule (1989), suggest that teachers do exercises in which students have an L2 term that they must define to the class without using any form of the target word. The rest of the class then guesses in writing. The student who wins is the one who has been best understood by his/her classmates.

Berry-Bravo (1994) addresses the issue of how to teach circumlocution in beginning Spanish classes. She advocates the use of basic vocabulary such as cosa 'thing', persona 'person,' lugar 'place,' as a basis of simple circumlocutory strategies. For example, she recommends that the noun vendedor 'salesman' be taught explicitly as una persona que vende cosas 'a person who sells things.' If instructors use circumlocution to present new material, she argues, they will in turn develop the skill in their students. In advanced classes, students should continue to develop their own definitions for words, in her view, as dictionary definitions are often far more complex than the word itself. As she

\footnotetext{
${ }^{13}$ See also Paribakht (1986) who advocates that the negotiation of meaning, including circumlocution, must be taught in the classroom, from early levels.
} 
notes, Swain (1985) argues that the ability of students to produce language often improves if they have to clear up messages that they do not understand. For Berry-Bravo, this supports the notion of using circumlocution in the second language classroom.

Dörnyei and Thurrell (1991) suggest that paraphrase and circumlocution be taught by having students give definitions that use relative clauses, for example, 'a table is where you can put the food you will eat.' Salazar (2006: 13), citing Robinson (1989), argues that in order to teach students circumlocution, "core words" should be taught, including subject pronouns and simple verbs (e.g., do, make, etc). She argues against memorization of word lists, with fill-in-the blank exercises, because these long-used strategies will not help students effectively communicate when they encounter an unknown lexical item.

Maleki (2010) proposes that a strategy that he labels "approximation strategy" which includes circumlocution, in his view, must be taught and modeled by the instructor. He recommends that teachers use this method to define new vocabulary words. Vocabulary words are taught via semantic links to existing words. Instructors should begin by giving a list of words that have the same semantic features as the words to be taught.

\subsection{The present proposal: Teaching circumlocution and dialectal lexical variation}

As discussed above in Section 1., lexical differences constitute the greatest difference among dialects, and can lead to a breakdown in comprehension, due to the importance of the lexicon. The proposal by Arteaga and Llorente (2009) is to teach the neutral term, the one most likely to be understood cross-dialectally. While this approach has great validity, we believe, it is only one tool that students should have at their disposal for effective communication.

In our view, circumlocution should be taught from the beginning in Spanish university-level classrooms. We simply do not have the luxury of allowing this skill to develop, given the pluricentricity of the language. We therefore advocate teaching students very simple ways to circumlocute when navigating vocabulary items that differ among dialects. In our view, the following expressions can explain most terms:

(15) Es algo (una cosa) que se pone 'It's something (a thing) that you wear' Es algo (una cosa) que se come 'It's something (a thing) that you eat' Es algo que se usa cuando (hace frío étc.) 'It's something that you wear when it's (cold, etc.)

Es algo que se encuentra (en una biblioteca, étc.) 'It's something that you find (in a library, etc.) 
Es donde se va si (se quiere nadar, étc.) 'It's where you go if (you want to swim, etc.)

Es una persona que... 'It's a person who...'

Es un lugar donde... 'It's a place where...'

Es ... (adjetivo descriptivo, color, étc.) It's (descriptive adjective, color,etc.)

Es sinónimo de... 'It's a synonym of ...'

Es lo opuesto de... 'It's the opposite of ...'

These expressions can then be expanded upon, if necessary. Note that this type of circumlocution is more complex than that advocated by Berry Bravo (1994). The reflexive se pone, 'you put on', is typically not taught until second semester Spanish ${ }^{14}$. Yet the structure will be used by native speakers, so it must be taught early on. The point here is that students must have a good understanding of the typical grammatical structure of definitions or else communication will break down.

Given that textbooks rarely teach the skill of circumlocution, we have developed sample exercises. An example of an exercise for beginners is the following:

The following exercise shows you how to understand and explain words from different Spanish dialects. Working in pairs, use the cards from your instructor, which give you the neutral term and the regional term. Do not give this information directly to your partner. Rather, using the model, explain to your partner the meaning of the words on your cards. Your partner should then match the neutral term with the regional variant. After s/he has done this, identify the dialect for your partner.

Modelo:

Información en la tarjeta: Pluma = lapicera (Argentina)

El/la estudiante: Una lapicera es una cosa que se usa para escribir. Se dice en Argentina.

término neutral término regional
1. escritorio
a) zafacón
2. pluma
b) libreta
3. carro
c) pupitre
4. cuaderno
d) bolígrafo
5. computadora
e) chao ${ }^{14}$ However, some expressions using se are often taught at the beginning, such as ¿Cómo se dice? 'How
do you say...?' 

6. piso
f) colegio mayor
7. pizarra
g) suelo
8. residencia
h) tablero
9. papelera
i) ordenador
10. adiós
j) coche

The words in the above exercise are among those vocabulary items given in textbooks within the first chapter of the elementary sequence. They refer to objects in the classroom, as well as common personal items. Therefore, this type of exercise could be done within two weeks after the course begins.

The instructor should have modeled circumlocution from the beginning of the semester and should have explained the concept of neutral terms. In the above exercise, students will be required to match two columns, one which contains the neutral lexical terms presented by their instructor, and another one which lists alternative lexical variants used across the Spanish speaking world.

Students will take turns explaining to each other the words that they are not familiar with. They will get the information from their instructor, who will distribute cards with a drawing of the object being described, labeled with the two different terms, used as synonyms. The cards also identify the dialects in which the alternative terms are used. Except for zafacón ('waste basket'), used in Puerto Rico, and chao ('Goodbye') used commonly in a variety of Latin American countries, all the other alternative lexical items are typical of Peninsular Spanish. The reason for this is that elementary textbooks in the U.S. often intersperse terms from Peninsular Spanish in the presentation of vocabulary (i.e., the cafeteria approach discussed above in Section 1).

Note that all of the words in (16) are nouns. Therefore, students will be able to base their circumlocution on the model. Students will be exchanging information by providing a simple definition of a word, using the expression given in the model (i.e., es una cosa que se usa... 'it's a thing that you wear...')

An example of an intermediate exercise is the following, which focuses on Argentinian clothing terms:

(17) En este ejercicio, van a aprender unas palabras de uso común en Argentina. Trabajen con sus compañeros(as) para encontrar el significado de las siguientes palabras. Deben estudiar el contenido de las tarjetas que su instructor(a) les ha dado e intercambiar la información:

1. una pollera

2. una campera

3. una remera 

4. una billetera
5. una cartera
6. unos anteojos
7. un saco
8. una bombacha
9. un pulóver
10. unas zapatillas

Modelo:

Estudiante A: ¿Qué quiere decir “malla”?

Estudiante B: "Malla” es lo que te pones para nadar.

Estudiante A: Entonces, es un sinónimo de "traje de baño."

Estudiante B: Sí.

The objective of this exercise, which focuses on regional variants from Argentina, is for students to practice circumlocution in the form of a definition or paraphrase. To complete the exercise in (17), students will work in pairs. The materials needed are a set of cards with the items depicted, labeled with the Argentinean lexical variant, and another set with only the Argentinean term, without any picture. Students should receive have of each, and take turns in the exchange of information. As the student who only has the lexical item written in his/her card ask about the meaning of this word, his/her partner should produce explanations and definitions that will allow them to make the connection between the neutral terms and the dialectally marked ones. Once the student understands the term, $\mathrm{s} / \mathrm{he}$ is to give the neutral term.

One set of cards would contain the following information:
1. una pollera (=falda)
2. una campera (=chaqueta)
3. una remera (=playera)
4. una billetera (=cartera)
5. una cartera (=bolsa)
6. unos anteojos (=lentes)
7. un saco (=una chaqueta de traje)
8. una bombacha (=pantaleta)
9. un pullover (=suéter)
10. unas zapatillas (=unos tenis, unos zapatos de tenis)

The expected results would be similar to the following definitions:

Estudiante A: ¿Qué significa una pollera? 
Estudiante B: Una pollera: Es un artículo de ropa para mujeres. Los hombres de Escocia también la usan.

Estudiante A: Entonces, es un sinónimo de falda.

Estudiante B: Sí.

Estudiante A: ¿Qué significa una campera?

Estudiante B: Es un artículo de ropa que se usa normalmente cuando hace frío. Puede ser de lana o de algodón.

Estudiante A: Entonces, es un sinónimo de chaqueta.

Estudiante B. Sí.

In the case of both the beginning and the intermediate exercise, students will manipulate neutral terms, while using circumlocution to communicate. However, unlike the exercise in (16), this one focuses solely on terms used in Argentina. The instructor should have the students do this exercise when the textbook covers that region.

Finally, an example of an advanced exercise is given in (18):

(18) El siguiente diálogo ocurre entre dos mujeres puertorriqueñas. Ellas emplean muchas palabras que son específicas de Puerto Rico:

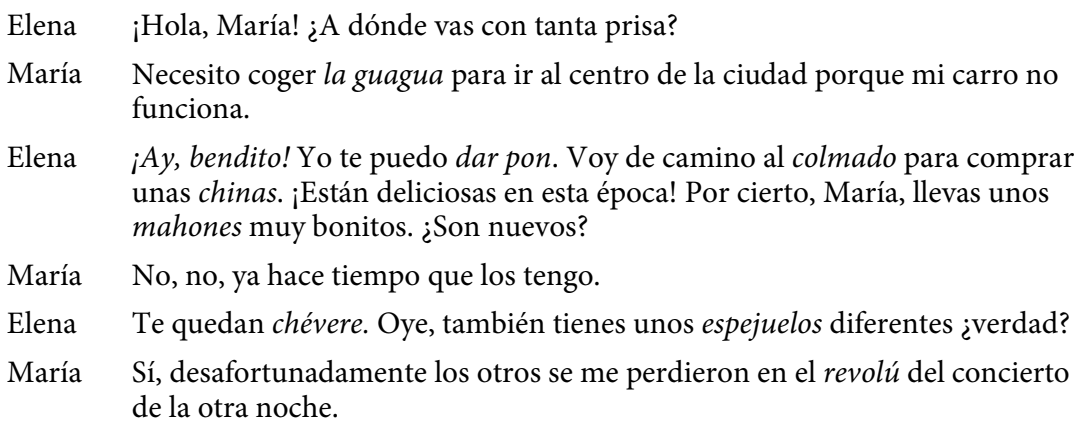

Trabaja con tu compañero(a). Lean el diálogo juntos(as), y luego miren las tarjetas. Éstas contienen información sobre los terminos en negrilla. Identifiquen las variantes regionales. Después den otras opciones para expresar los elementos léxicos.

In the above exercise, students are presented with a dialogue between two women from Puerto Rico, who use lexical items and idioms that are specific to that dialect. In order to complete the above exercise, the students receive cards which contain information, in the form of circumlocution, regarding the regional terms that appear in the dialogue.

The following is the information the students will have on their cards:

Información de las tarjetas: 
1. Es una expresión idiomática que se puede usar en muchos contextos. Puede significar lástima, compasión, etc.

2. Es una situación desordenada. Normalmente ocurre cuando hay mucha gente y mucho movimiento.

3. Es una expresión que se usa cuando una persona no tiene medio de transporte, y tú le ofreces llevarle a algún lugar.

4. Es una cosa que se utiliza cuando no ves bien.

5. Es una fruta muy común para hacer el jugo que se toma por la mañana con el desayuno. Es de color anaranjado.

6. Es un tipo de pantalones. Es ropa informal, que los jóvenes usan con mucha frecuencia.

7. Es la tienda donde puedes comprar alimentos.

8. Es una expresión idiomática que se usa para indicar que algo está muy bien.

After students match the regional terms with the definitions, they give other dialectal variants, such as the following:

¡Ay bendito! En otros países dicen ¡Ay, Dios mío!, ¡Qué lástima!, ¡Qué pena! ¡Lo siento!

revolú Una palabra que usan en otros países es confusión.

dar pon En otros países dicen dar cola o dar aventón

Using (16)- (18) above as a model, the instructor can easily create his/her own exercises based directly on the textbook used. These kinds of exercise give students a firm grasp of regional variation in the Spanish lexicon.

\section{Conclusion}

In this paper, following Arteaga and Llorente (2009), we have argued for the need to help students become aware of dialectal differences in the Spanish lexicon, where dialectal variation is the most prominent. As they note, when the time comes for our students to use their language skills in the real world, they will do so by interacting with speakers from a wide variety of geographical origins, given the pluricentricity of Spanish.

We have also agreed with Arteaga and Llorente regarding the necessity of teaching dialectally neutral terms, although we have suggested that this skill must be supplemented by the use of circumlocution. The reasons for this include the fact that it is not always easy to identify what the neutral term is, given the variety of lexical items across the Spanish speaking world to designate a given object. Moreover, although a term seems to be used more commonly, it is not always the one that has the most currency. The situation is complicated, because most college textbooks do not consistently ad- 
dress lexical variants. Finally, the teacher might lack the linguistic training to decide what the neutral term is.

In this paper, we have considered circumlocution in broad terms, so that it includes the use of definitions, paraphrase, analogy, synonyms (or even superordinate terms), and word coinage. We have also viewed it as a strategy that is both receptive and productive, that is, students need to both understand it when either a NS or a NNS uses it to negotiate the meaning of an unknown word, and use it when they are trying to make themselves understood.

We have noted that circumlocution is a strategy that successful language students should be able to master, according to the ACTFL Guidelines, at the Intermediate, Intermediate-High, and Advanced speaking levels. Researchers have generally agreed with the usefulness of circumlocution (see, inter alia, Willems, 1987; Ellis et alii, 1994; De la Fuente, 2002; and Salazar, 2006). We have suggested, following Berry Dörnyei and Thurrell (1991), Bravo (1994), and Salazar (2006), among others, that even at lower levels of language learning, it is a useful strategy for students to develop. We have advocated the overt teaching of circumlocution, by having the teacher model its different varieties (definition, paraphrase, etc.) in the presentation of vocabulary items. To this end, we have provided sample exercises that can be incorporated into the Spanish language classroom. These, combined with the use of the dialectally neutral term, should allow our students to navigate dialectal lexical differences from the beginning of their Spanish-language studies.

Received: 25.05 .2011

Accepted: 19.10-2011

\section{References}

ACTFL Proficiency Guidelines:

http://www.actfl.org/i4a/pages/index.cfm?pageid $=4236$

www.census.gov/prod/cen2010/briefs/c2010br-02.pdf

Arteaga, D. \& L. Llorente (2009): Spanish as an international language: Implications for teachers and learners. Clevedon, Multilingual Matters.

Azevedp. M. (1992): Introducción a la lingüística española. Upper Saddle River NJ, Prentice-Hall.

Berry-Bravo, J. (1994): “Teaching the art of circumlocution”, Hispania, 76, págs. 371377.

Bialystok, E. (1983): "Some factors in the selection and implementation of communication strategies". In Faerch, C. and G. Kasper (ed.): Strategies in Interlanguage Communication, Harlow, England, Longman, págs.100-118. 
Bialystok, Ellen, and M. Fröhlich. (1980): "Oral communication strategies for lexical difficulties”, Interlanguage studies bulletin-Utrecht, 5, págs. 3-30.

Brooks, F. (1992): “Can we talk?”. Foreign Language Annals, 25 (1), págs. 59-71.

Butterfield, J. (ed.) (2005): Collins dictionary: español-inglés English-Spanish. New York, HarperCollins.

Canale, M. and M. Swain. (1980): 'Theoretical bases of communicative approaches to second language teaching and testing", Applied Linguistics, 1, págs. 1-47.

Cook, V. J. (1997): "The consequences of bilingualism for cognitive processing". In De Groot, A. M. B. and J. F. Kroll (eds.): Tutorials in Bilingualism, Mahwah NJ, Erlbaum, págs. 279-300.

Cook, V. J. (2008): Second Language Learning and Language Teaching. London: Hodder.

De la Fuente, M. J. (2002): "Negotiation and oral acquisition of L2 vocabulary: The roles of input and output in the receptive and productive acquisition of words", SSLA, 24, págs. .81-112.

Dörnyei, Z., and S. Thurrell (1991): "Strategic competence and how to teach it", ELT Journal, 45, págs. 16-23.

Ehrlich, S., P Avery and C. Yorio. (1989): "Discourse structure and the negotiation of comprehssible input”, Studies in Second Language Acquisition, 11, págs. 397-414.

Ellis, R., Y. Tanaka and A. Yamazaki (1994): "Classroom interaction, comprehension and L2 vocabulary acquisition”, Language Learning, 44, págs. 449-491.

Furman, N., D. Goldberg and N. Lusin (2009): Enrollments in Languages Other Than English in the United States Institutions of Higher Education, Fall 2009: www.mla.org/2009_flenrollmentsurvey

Gass, S. (1988): "Second language vocabulary acquisition", Annual Review of Applied Linguistics, 9, págs. 92-106.

Gass, S. and L. Selinker (1986) (eds.): Language transfer in language learning, Amsterdam, John Benjamins.

Gass, S. and L. Selinker (2001): Second language acquisition: An introductory course. Mahjaw, NJ: Laurence Erlbaum.

Gass, S., and M. Varonis (1994): "Input, interaction, and second language production", Studies in Second Language Acquisition, 16, págs. 283-302.

Hershberger, R., S. Navey-Davis and G. Borrás Álvarez (2008): Plazas. Lugar de encuentros (3rd edn). Boston, Thomson-Heile.

Jourdain, J. (2000): "A native-like ability to circumlocute", Modern Language Journal, 84, págs. 184-195.

Kellerman, E., T. Ammerlan, T. Bongaerts and N. Pouilsse (1990): "System and hierar- 
chy in L2 compensatory strategies". In Scarcella, R., Anderson E., and S. Krashen (eds.): Developing communicative competence in a second language, New York, Newbury House, págs. 163-178.

Kellerman, E., B. Weltens and T. Bongaerts (eds.). (1996): EUROSLA 6: A selection of papers. Amsterdam, VU Uitgeverij.

Krashen, S. (1991): "The input hypothesis: An update". En Alatis, J. (ed.): Georgetown University Round Table on Languages and Linguistics. Washington DC, Georgetown University Press, págs. 409-431.

Lewis, M. P., (ed) (2009): Ethnologue: Languages of the World, (16th edn.). Dallas: SIL International. Web edition at: http://www.ethnologue.com.

Liskin-Gasparo, J. (1996): "Circumlocution, communication strategies, and the ACTFL proficiency guidelines: An analysis of student discourse”, Foreign Language Annals, 29, págs. 317-330.

Long, M. (1993): “Assessment strategies for SLA theories”, Applied Linguistics, 1413, págs. 225-249.

Loschky, L. (1989): "The effects of negociated interaction and premodified input on second language comprehension and retention", Occasional paper no. 16, Honolulu, Hawaii, University of Hawaii at Manoa, Department of English as a Second Language.

Loschky, L. (1994): "Comprehensible input and second language acquisition. What is the relationship?", Studies in Second Language Acquisition, 16, págs. 303-324.

Maleki, A. (2010): "Techniques to teach communication strategies", Journal of language teaching and research, 1, págs. 640-646.

Nation, I.S.P. (1990): Teaching and learning vocabulary. New York, Newbury House.

O'Malley, J. M. (1987): “The effects of training in the use of learning strategies on learning English as a second language". In Wendin A., and J. Ribin (eds.): Learner Strategies in Language learning, Cambridge, Prentice Hall, págs. 133-143.

Oxford, R. and M. Nyikos. (1989): "Variables affecting choice of language learning strategies by University students", The Modern Language Journal, 73, págs. 291-300.

Paribakht, T. (1985): "Strategic competence and language proficiency", Applied Linguistics, 6, págs. 132-144.

Paribakht, T. (1986): "On the pedagogical relevance of strategic competence", TESL Canada Journal/Revue TESL du Canada, 3 (2), págs. 22-36.

Pew Hispanic Center, (2009): Statistical Portrait of Hispanics in the United States, 2009: Detailed Hispanic Origin.

Pica, T. (1991): "Classroom interaction, participation, and comprehension: Redefining relationships”, System, 19, págs. 437-452.

Pica, T. (1992): "Research on negotiation: what does it reveal about second-language 
learning conditions, processes, and outcomes?”, Language Learning, 44, págs. 493527.

Pica, T., L., N. Holliday, N. Lewis, D. Berducci, and J. Newman (1981): "Language learning through interaction: What role does gender play?", Studies in Second Language Acquisition, 13, págs. 343-376.

Pica, T., L. Holliday, N. Lewis, and L. Morgenthaler. (1989): "Comprehensible output as an outcome of linguistic demands on the learner", Studies in Second Language Acquisition, 11, págs. 63-90.

Pica, T., R. Young and C. Doughty (1987): "The impact of interaction on comprehension”, TESOL Quarterly, 21 (4), págs. 737-758.

Robinson, P. (1989): “A rich view of lexical competence”, ELT Journal, 43, págs. 274282.

Rubin, J. (1975): "What the 'Good Language Learner' can teach us", TESOL Quarterly, 9, págs. 41-51.

Salazar Campillo, P. (2006): "The use of circumlocution in the foreign language context”, Porta Linguarum, 5, págs. 7-15.

Salomone, A. M., and F. Marsal. (1996): "How to avoid language breakdown? Circumlocution!”, Foreign Language Annals, 30, págs. 473-484.

Savignon, S. J. (1983): Communicative competence: Theory and classroom practice. Reading, MA, Addison-Wesley.

Swain, M. (1985): "Communicative competence: Some roles of comprehensible input and comprehensible output in its development" In Gass, S. M., and C. G. Madden (eds.): Input and Second Language Acquisition, Rowley MA, Newbury House, págs. 235-253.

Tarone, E. (1977): "Conscious communication strategies in interlanguage: a progress report”. In Brown, D., C. Yorio and R.M. Crymes (eds.): On Tesol '77. Teaching and Learning ESL. Washington, D.C., TESOL.

Tarone, E. and G. Yule. (1989): Focus on the language learner: Approaches to identifying and meeting the needs of second language learners. Oxford, Oxford University Press.

United States Census Bureau. Overview of Race and Hispanic Origin. 2010 Brief. www.census.gov/prod/cen2010/briefs/c2010br-02.pdf

Van Patten, B. (2004): Processing Instruction: Theory, Research, and Commentary. Boston, Erlbaum.

Willems, G. (1987): "Communication strategies and their significance in foreign language teaching”, System, 15, págs. 351-364. 